Portland State University

PDXScholar

Fall 2004

\title{
Can Cooperative Service Solve the Grey Literature Challenge?
}

Sherry Buchanan

Portland State University, sherryb@pdx.edu

Cyril Oberlander

SUNY Geneseo

Rose M. Jackson

Portland State University

Follow this and additional works at: https://pdxscholar.library.pdx.edu/ulib_fac

Part of the Library and Information Science Commons

Let us know how access to this document benefits you.

\section{Citation Details}

Buchanan, S., Jackson, R. \& Oberlander, C. (Fall 2004). Can Cooperative Service Solve the Grey Literature Challenge? OLA Quarterly, 10 (2/3), 5-9.

This Article is brought to you for free and open access. It has been accepted for inclusion in Library Faculty Publications and Presentations by an authorized administrator of PDXScholar. Please contact us if we can make this document more accessible: pdxscholar@pdx.edu. 


\section{Can Cooperative Service Solve the Grey Literature Challenge?}

\section{by Sherry Buchanan \\ Interlibrary Loan Specialist \\ Millar Library, \\ Portland State University}

\section{Rose M. Jackson \\ Urban \& Public Affairs Librarian Millar Library, \\ Portland State University}

\section{and by Cyril Oberlander}

Head of Interlibrary Loan Millar Library,

Portland State University

\section{Introduction}

Recent articles have documented the surge of student and faculty reliance on the Internet and search engines like Google as sources for bibliographies, and many articles have explored how the Internet has impacted students' views of librarianmediated reference techniques. (Harley et al, 2001) Researchers find Web bibliographies and bring them to the reference desk expecting the library to hold the items. Quite often these bibliographies are very specific and relevant to a particular area of research; however, a casual glance and a few catalog searches elicit that the majority of the cited materials are not locally held. In many cases, the reference librarian's first response is to refer patrons to interlibrary loan, but perhaps more instruction could occur before the referral. In this article, we explore the interplay between reference and interlibrary loan services in light of post-modern research styles, and how reference and interlibrary loan (distinct service points) can seamlessly address grey literature research needs.

What is grey literature? In the broad sense, grey literature is material that is not readily available through normal channels. Other libraries, wholesalers, or distributors cannot supply it. It is often produced by government agencies, educational institutions, corporations, professional associations, organizations, societies, and research centers. It takes the form of conference presentations, limited publications, dissertations, pamphlets, reports, and Web pages; each has limited distribution, availability, audiences, and life cycles. (Alberani, 1990; Auger, 1994)

\section{PSU Interlibrary Loan and Grey Literature: A Case Study}

At Portland State University, an average interlibrary loan request takes less than a minute to send. A staff member spends as long as thirty minutes attempting to send one request for a piece of grey literature. It is interesting to assess how quickly Portland State University's Interlibrary Loan department fills different requests. It is particularly useful to look at how different requests call into question policies and relationships between library services. In the following example, we see how a request for grey literature is handled, and we learn how the user's requests for similar materials are addressed by the staff.

Portland State's Interlibrary Loan (PSU ILL) receives an article request for "O.W.L. Farm, Oregon by Osa in Maize \#9, published in Minneapolis, Summer 1986." (http://www-lib.usc.edu/ retter/ teehouses.html) The citation lacks formality-bibliographic information typically seen in a complete scholarly citation is not there; it does not include the author's first name or initials, nor page numbers. ILL processing starts...

- The first task is to search OCLC Passport, knowing that single word titles can be difficult to find. In fact, if we do a title search alone for Maize in OCLC, there are 5,391 hits. To narrow down results and obtain an ISSN, JAKE at http://

jake.lib.sfu.ca/, a great bibliographic verification tool is used; however, in this case, the search yields no results.

- The citation is reanalyzed. Subjectspecific databases, such as Sociological Abstracts, or print indexes, such as Access or the Alternative Press Index are checked.

- In OCLC Passport, common search strategies are used, including keyword searching and qualifier limits; however, there are still too many serial titles to determine the correct one.

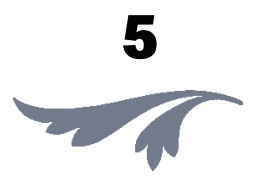


- Next, Google is used to try to locate a cross-reference, and the Web bibliography (http://wwwlib.usc.edu/\%7Eretter/ teehouses.html) from which our patron has extracted her citation is found. (http://www-lib.usc.edu/ $\sim$ retter/teehouses.html) This is confirmed later, when we learn that our user has submitted eleven other requests from the same source. The reference comes from Little Houses on Women's Lands, a piece of grey literature, presented at the first Northwest Gay and Lesbian History Conference, Tacoma, Washington, October 23-25, 1998.

- The patron has accurately copied the citation from the bibliography, and with no additional information, we are still unable to locate a lending library. At that point, we might have given up, but experience tells us that we can use Google to our advantage. We search for keywords, "Maize," "Minneapolis," and "lesbian," hoping to locate more information about the serial. We find the University of Oregon's Feminist and Lesbian Periodical Collection, a Web site that identifies Preston Hollow as the publisher. (http:// libweb.uoregon.edu/speccoll/ exhibits/lesbianper/index.html)

- Now, we go back to OCLC Passport and search for the title, Maize, and the publisher location, "Hollow," and bingo: one search, one record! We send the request to three potential lenders.

- In about eight days, the request is cancelled because none of the potential suppliers has the issue. We notify the user that no sources exist, and we recommend that the user contact the author or the subject specialist for additional assistance.

Of the thirty-six citations listed in the bibliography (http://www-lib.usc.edu/ $\% 7$ Eretter/teehouses.html), our patron submitted twelve requests to Portland State University's Interlibrary Loan department, five of which were obtained with ease. Seven of the twelve requests were for grey literature, and of those, none were obtained even though we could locate holders of Maize. Of the seven grey literature requests, four were article requests from the journal Maize, and the other three were loan requests, for which no OCLC records or non-OCLC sources could be found.

PSU ILL cancels 2.5 percent of its requests, and most of that percentage represents requests for grey literature. Although 2.5 percent appears low, in this case study, our fill rate for seven requests was zero percent. As the number of requests for grey literature increases, the inability to fill these requests will negatively impact user satisfaction with the library and the overall borrowing fill rate, which is currently about 85 percent (69.29 percent filled by other libraries and 16 percent considered "filled" because items were available in-house or through Summit, a union catalog for Oregon, Washington and Idaho academic libraries).

\section{Cancelling Grey Literature Requests at PSU Interlibrary Loan}

Between January 1, 2003 and June 1, 2004 , PSU ILL cancelled 672 requests; about 2.5 percent of those were unfilled because there were no suppliers.

PSU ILL cancels requests if:

- No OCLC supplier exists. 


$\mathrm{VOI} 10 \mathrm{NO} 2 / 3 \cdot \mathrm{FALL} 2004$

- No alternative sources can be found.

- No back-issues are available from the publisher.

Our response to hard to fill requests, some of which include grey literature, varies with the difficulty level of the request. We may:

- Decide to contact a user for a copy of the original citation.

- Confer with a subject specialist for additional help.

- $\quad$ Review grey literature pathfinders. (Auger, 1994; Mathews, 2004; University of Texas, 2004)

- Contact an outside source, such as the article author or publisher.

- Suggest other titles or refer the patron to a subject specialist for a reference interview.

- $\quad$ Suggest the user attend a bibliographic instruction session to learn new research stategies.

Our current e-mail cancellation notice recommends that the user contact the author and/or library subject specialist, and if possible, we include the author's email address. However, we find ourselves asking these questions:

- When does ILL's job end? Should PSU ILL see authors as "lenders" and send them requests, or should we cancel requests and promote communication between researchers and authors?

- How does our cancellation of requests impact student learning and satisfaction with the library?
- How and at what point should subject specialists be involved?

\section{Synthesis: A Call for Collaborative Library Services and Cross-training}

Handling grey literature requests invites us to take opportunities to teach users by promoting good research strategies. Many users could benefit from instruction on evaluating sources, obtaining information from other researchers, and using library databases to locate alternative titles by the same author.

With the rise of Web bibliography usage, we expect to see increases in cancelled ILL requests. Most alarming is the fact that when a user's research question relies almost entirely upon grey literature sources, the library's resources and services appear inadequate. For the user in our case study, our success rate was approximately 42 percent (we filled five of twelve requests).

What can we do to improve how we handle grey literature requests? With increased numbers of requests for grey literature, reliance on a central bibliographic resource such as OCLC becomes problematic. There is a need for an integrative approach to handling grey literature requests. We find that collaborative library services are the optimum solution rather than letting users get lost between interlibrary loan and reference. Short of an integrated service point, a level of process integration and staff cross training may be achieved by creating a feedback loop for handling grey literature requests.

Fundamentally, achieving any level of library service integration requires cross training, shared service philosophies, and knowledge management. A dialogue about the experiences within libraries is a good 